Short Note

\title{
Information Disclosure on Hazards from Industrial Water Pollution Incidents: Latent Resistance and Countermeasures in China
}

\author{
Yanhong Tang ${ }^{1}$, Xin Miao ${ }^{2, *}$, Hongyu Zang ${ }^{2}$ and Yanhong Gao ${ }^{1}$ \\ 1 College of Resources and Environment, Northeast Agricultural University, Harbin 150030, China; \\ tangyanhong@aliyun.com (Y.T.); gaoyh@neau.edu.cn (Y.G.) \\ 2 School of Management, Harbin Institute of Technology, Harbin 150001, China; zanghongyu@hit.edu.cn \\ * Correspondence: xin.miao@aliyun.com
}

Received: 18 January 2018; Accepted: 30 April 2018; Published: 8 May 2018

\begin{abstract}
China has suffered frequent water pollution incidents in recent years, and information disclosure on relevant hazards is often delayed and insufficient. The purpose of this paper is to unearth the latent resistance, and analyze the institutional arrangements and countermeasures. After reviewing representative journal literature about environmental information disclosure, this paper provides a theoretical review based on a comparison of the ontological differences between stakeholder theory and fraud triangle theory. A tentative application of fraud triangle theory as a means of explaining the phenomenon is proposed. Empirical analysis is undertaken to verify the tentative theoretical explanation. Based on news reports from Chinese official news websites, content analysis on longitudinal case evidence of representative water pollution incidents is applied, to contribute to unearthing the mechanism of the latent resistance towards information disclosure. The results show that local government agencies have a dominant position vis a vis information disclosure, but that some important actors rarely participate in information disclosure, which provides a chance for local government agencies' information disclosure to commit fraud. The phenomenon, its essence, and proposed countermeasures are discussed and explained by referring to recent governmental environmental practices in China. Promising research topics are illuminated, providing enlightenment for future study.
\end{abstract}

Keywords: industrial water pollution incident; hazards; environmental information disclosure; fraud triangle theory; longitudinal cases; institutional arrangements; environmental governance; countermeasures; promising research topics

\section{Introduction}

One-fifth of rivers contain high concentrations of pollutants [1]. Water pollution in China poses huge health risks [2], and is the cause of huge economic losses [3]. Frequent water pollution incidents and delayed information disclosure on the associated hazards have become an increasing concern in China, and have also attracted international attention. For example, the hazards from the Songhua River pollution incident endured a concealment of nine days. An earlier official statement informed the public that only water and carbon dioxide came from the chemical plant explosion, and that no pollutant entered the river system. Finally, the pollutants drifted to Russia and caused a diplomatic conflict. Similarly, news of pollution caused by the Zijin Mining Corporation was concealed for nine days. The Changzhi aniline leakage was concealed for 5 days. Delayed information disclosure on hazards from industrial water pollution incidents result in reduced response times, and cause panic downstream. It is inefficient to enforce information disclosure on the hazards stemming from industrial 
water pollution incidents, despite the fact that the Environmental Information Disclosure Decree (EIDD) was issued by Ministry of Environmental Protection (MEP) of China, and the Guidelines of Environmental Information Disclosure of Listed Companies was published by Shanghai Stock Exchange, which specified how and in what time frame information should be provided to the public, and also prescribed relevant laws and penalties; moreover, MEP had already promoted information disclosure programs for listed companies in an official guideline named Key Points of National Pollution Prevention and Control of 2011. However, the enforcement of these policies and regulations were problematic, and concealment and delay were still frequent. Environmental information disclosure (EID) has drawn increasing attention from academia in recent decades, especially for EID in China, implying that problems such as reluctant disclosure, superficial disclosure, delayed disclosure and selective disclosure persist.

\section{Review on Representative Journal Literature about EID}

The online Science Citation Index Expanded (SCIE), Social Science Citation Index (SSCI), and Arts $\&$ Humanities Citation Index (A\&HCI) databases were used to retrieve journal literature published up to 22 March 2018. These databases include rigorous journal papers [4] that can be seen as representative journal literature in a given field [5].

By searching for the topic "environmental information disclosure", we obtained the 58 publications. The publication numbers per year, obtained using the "Create Citation Report" function of the Web of Science, are presented in Figure 1, which illustrates an increasing tendency in the numbers of publications per year. The resulting numbers of citations per year are shown as Figure 2, which illustrates an obvious increasing tendency. Therefore, this research field is drawing more and more academic attention.

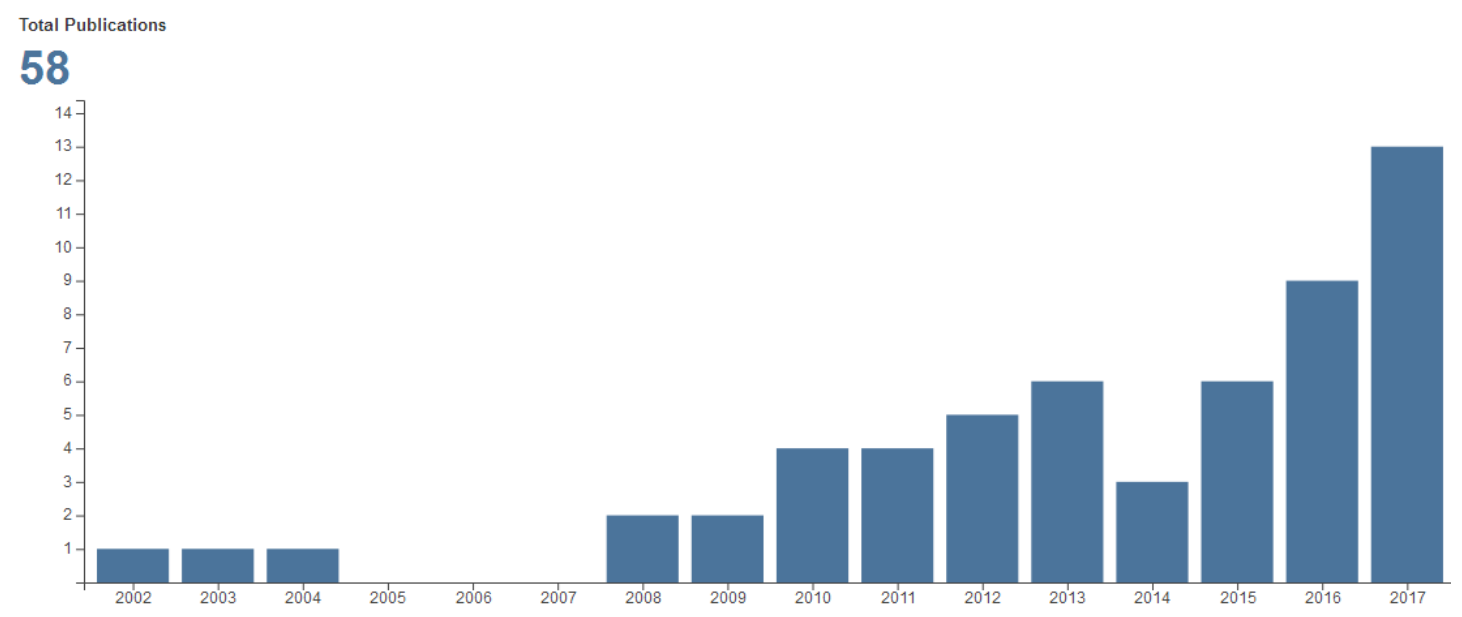

Figure 1. The publication numbers per year.

By analyzing via using the "Analyze Results" function of the Web of Science, and pre-setting the minimum record count (threshold) to 3, the resultant top field categories of Web of Science were obtained (shown in Figure 3). This presents an outline of the major disciplines relevant to EID issues. The resulting top countries/regions in terms of publication numbers are shown in Figure 4, which shows that People's Republic of China ranks first in this list. The top authors in terms of numbers of publications are shown in Figure 5, which indicates that most are Chinese authors. These results partially imply numerous problems related to EID in China. The top journals, in terms of publication numbers, are shown in Figure 6; the top authors in terms of publication numbers are shown in Figure 7; information on the top ten papers in terms of numbers of citations (from Web of Science Core Collection) is shown in Table 1. Such information may help readers to get a basic understanding upon this research direction. 


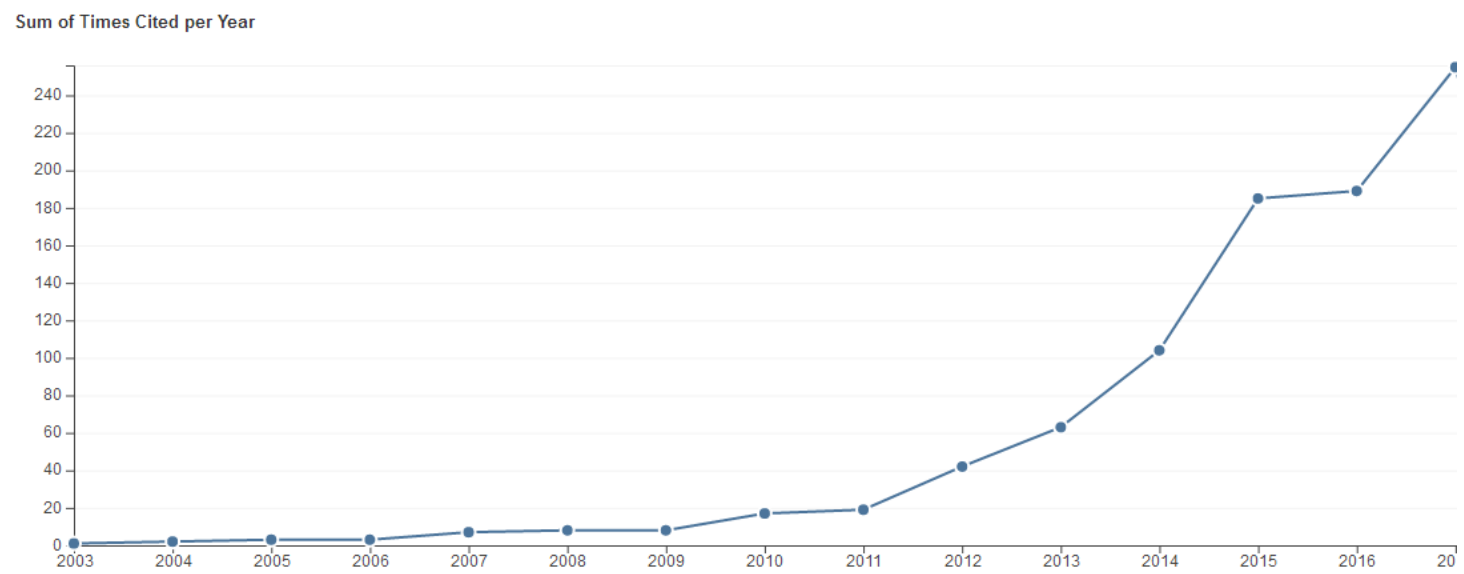

Figure 2. The sum of times cited per year.

\begin{tabular}{r|c|c|c|}
\hline \multicolumn{1}{|c|}{ Field: Web of Science Categories } & Record Count & $\%$ of 58 & Bar Chart \\
\hline ENVIRONMENTAL SCIENCES & 20 & $34.483 \%$ & \\
BUSINESS & 16 & $27.586 \%$ & \\
\hline ENVIRONMENTAL STUDIES & 16 & $27.586 \%$ & \\
\hline GREEN SUSTAINABLE SCIENCE TECHNOLOGY & 11 & $18.966 \%$ & \\
MANAGEMENT & 11 & $18.966 \%$ & \\
\hline BUSINESS FINANCE & 7 & $12.069 \%$ & \\
\hline ENGINEERING ENVIRONMENTAL & 7 & $12.069 \%$ & \\
\hline ECONOMICS & 6 & $10.345 \%$ & \\
ETHICS & 5 & $8.621 \%$ & \\
\hline LAW & 3 & $5.172 \%$ & \\
\hline MULTIDISCIPLINARY SCIENCES & 3 & $5.172 \%$ & \\
\hline POLITICAL SCIENCE & 3 & $5.172 \%$ & \\
\hline
\end{tabular}

Figure 3. The top field categories in terms of publication numbers.

\begin{tabular}{|r|c|c|c|} 
Field: Countries/Regions & Record Count & $\%$ of 58 & Bar Chart \\
\hline PEOPLES R CHINA & 31 & $53.448 \%$ & \\
USA & 13 & $22.414 \%$ & \\
\hline NETHERLANDS & 6 & $10.345 \%$ & $\square$ \\
JAPAN & 4 & $6.897 \%$ & $\square$ \\
TAIWAN & 3 & $5.172 \%$ & \\
\hline
\end{tabular}

Figure 4. The top countries in terms of publication numbers. 


\begin{tabular}{|r|c|c|c|}
\hline Field: Authors & Record Count & $\%$ of 58 & Bar Chart \\
\hline ZENG SX & 7 & $12.069 \%$ & \\
\hline ZHANG L & 5 & $8.621 \%$ & $\square$ \\
\hline HE GZ & 4 & $6.897 \%$ & $\square$ \\
\hline TAM CM & 4 & $6.897 \%$ & $\square$ \\
\hline LI DY & 3 & $5.172 \%$ & $\square$ \\
\hline LIU XB & 3 & $5.172 \%$ & $\square$ \\
\hline LU YL & 3 & $5.172 \%$ & $\square$ \\
\hline MENG XH & 3 & $5.172 \%$ & $\square$ \\
\hline MOL APJ & 3 & $5.172 \%$ & $\square$ \\
XU XD & 3 & $5.172 \%$ & $\square$ \\
\hline
\end{tabular}

Figure 5. The top authors in terms of publication numbers.

\begin{tabular}{|c|c|c|c|}
\hline Field: Source Titles & Record Count & $\%$ of 58 & Bar Chart \\
\hline JOURNAL OF CLEANER PRODUCTION & 7 & $12.069 \%$ & $\square$ \\
\hline JOURNAL OF BUSINESS ETHICS & 5 & $8.621 \%$ & $\square$ \\
\hline JOURNAL OF ENVIRONMENTAL LAW & 3 & $5.172 \%$ & ! \\
\hline SUSTAINABILITY ACCOUNTING MANAGEMENT AND POLICY JOURNAL & 3 & $5.172 \%$ & - \\
\hline
\end{tabular}

Figure 6. The top journals in terms of publication numbers.

\begin{tabular}{|r|c|c|c|}
\hline Field: Authors & Record Count & $\%$ of 58 & Bar Chart \\
\hline ZENG SX & 7 & $12.069 \%$ & \\
\hline ZHANG L & 5 & $8.621 \%$ & $\square$ \\
\hline HE GZ & 4 & $6.897 \%$ & $\square$ \\
\hline TAM CM & 4 & $6.897 \%$ & $\square$ \\
\hline LI DY & 3 & $5.172 \%$ & $\square$ \\
\hline LIU XB & 3 & $5.172 \%$ & $\square$ \\
\hline LU YL & 3 & $5.172 \%$ & $\square$ \\
\hline MENG XH & 3 & $5.172 \%$ & $\square$ \\
\hline MOL APJ & 3 & $5.172 \%$ & $\square$ \\
XU XD & 3 & $5.172 \%$ & $\square$ \\
\hline
\end{tabular}

Figure 7. The top authors in terms of publication numbers. 
Table 1. The information of the top ten papers in terms of times cited.

\begin{tabular}{cccc}
\hline Authors & Publication Years & Journal Names & $\begin{array}{c}\text { Times Cited (from Web of } \\
\text { Science Core Collection) }\end{array}$ \\
\hline Liu and Anbumozhi & 2009 & Journal of Cleaner Production & 135 \\
\hline Fifka & 2013 & $\begin{array}{c}\text { Business Strategy and } \\
\text { The Environment }\end{array}$ & 107 \\
\hline Zeng et al. & 2012 & Journal of Business Ethics & 73 \\
\hline Stephan & 2002 & Social Science Quarterly & 58 \\
\hline Zeng et al. & 2010 & Journal of Cleaner Production & 48 \\
\hline Cho et al. & 2012 & $\begin{array}{c}\text { Accounting Auditing \& } \\
\text { Accountability Journal }\end{array}$ & 36 \\
\hline Hassan and Ibrahim & 2012 & $\begin{array}{c}\text { Corporate Social Responsibility and } \\
\text { Environmental Management }\end{array}$ & 32 \\
\hline He et al. & 2013 & $\begin{array}{c}\text { Renewable \& Sustainable } \\
\text { Energy Reviews }\end{array}$ & 32 \\
\hline Kuo et al. & 2012 & $\begin{array}{c}\text { Corporate Social Responsibility and } \\
\text { Environmental Management }\end{array}$ \\
\hline Lewis et al. & 2014 & Strategic Management Journal & 31 \\
\hline
\end{tabular}

Through skimming the 58 publications, key clusters can be classified as follows:

Corporate EID was considered as a proxy of corporate environmental responsibility [6-11].

The relationship (mainly in terms of statistical relevance) between EID and some indices/tendencies/decisions/performances: EID and marketization level [12]; EID and investment allocation decisions [13]; EID and the resident's willingness to engage in environmental activism [14]; EID and market responses [15]; EID and waste discharge reduction [16]; EID and firm value [17]; EID and the consequent possibility of receiving an award [18]; the negative relationship between EID and financial performance [19]; EID and investors' decisions on the stock exchange [20]; EID and reducing informational asymmetries, and putting pressure on firms to reduce emissions [21]; EID and eco-efficiency [22].

The bottlenecks to promote EID and/or promising improvements [23-28].

The influencing factors on EID [29-40].

Representative results and comments are summarized as follows:

There was a negative relationship between EID and financial performance based upon 950 observations from 475 Chinese listed companies between 2013 and 2014, implying that Chinese firms have little motivation for EID or to improve environmental performance [11]. Nearly $40 \%$ of the sample listed companies in China failed to offer basic EID, and corporate EID was aimed to cater to the government's environmental concerns [41]. Chinese environmentally sensitive industries have a tendency to disclose more information about their environmental protection actions [42]. Some disclosed information appeared to be insufficient to reveal practical information and fulfill stakeholders' requirements [43]. Some EID were selective or limited disclosures for "greenwashing" [16]. The overwhelming majority of observations of disclosures were not quantitatively material, and disclosing firms did not exhibit improved subsequent environmental performance relative to non-disclosing companies [29]. There was an inverse relationship between the marketization level and corporate EID, implying that EID problems cannot be solved by market development itself [12]. Evaluation of the effectiveness of EID to reduce informational asymmetries and put pressure on firms to reduce emissions [21] was proposed. The limited extent of public participation was an important contributor to the EID problem [24]. Effective public participation in China was substantially hindered by participatory mechanisms and capacity [25]. Information disclosure law was suggested to encourage public participation [44]. The implementation of China's EID system was facing obstacles; promising improvements may include effective public participation, independent evaluation and 
supervision, exchange of experiences among provincial environmental protection department, and consolidating the legal status of EID [23]. Top-down pressure on EID resorted to leadership but failed to draw public attention. Bottom-up pressure on EID may empower active public involvement in environmental issues [45]. Political and institutional defects constrained some actors, including Non-Governmental Organizations (NGOs) in EID related activities [26]. Interest groups served as the main intermediaries for EID. Incentives and stakeholders are critical for corporate EID [18]. Multiple different patterns of stakeholders' interactions contributed to corporate EID improvement [46].

\section{Theoretical Review}

Relevant studies mostly focus on corporate routine EID, and accordingly, stakeholder theory is often used as a mainstream theory for previous studies [44,47]. However, when a severe pollution incident occurs in China, it is usually up to the local government to decide whether or not to disclose the information, since it is related to the social stability of the local area, and local government takes charge and is sensitive to local social stability problems. When local governments become the main body of information disclosure, stakeholder theory may fail to serve as a cornerstone to explain the phenomena. A new theoretical framework should be exploited.

We propose the use of fraud triangle theory to interpret delayed or false information disclosure. Fraud triangle theory has been extensively used in the research of business, accounting and auditing. Three elements common to all frauds are perceived pressure, perceived opportunity, and a way of rationalizing the fraud [48]. This paper proposed the use of fraud triangle theory to interpret local government's fraud vis a vis information disclosure.

The ontological differences between stakeholder theory and fraud triangle theory are discussed as follows:

For legitimacy: stakeholder theory is usually applied to normal development in corporate organizations [49,50]; the fraud triangle theory is usually applied to illegal behavior of either organizations or individuals [51].

For a level of focus: stakeholder theory is usually relevant to the strategy level of corporations [52]; fraud triangle theory is usually relevant to unethical tactic behavior of organizations or individuals [53].

For a time span: stakeholder theory is usually about the long-term interests of corporations [54]; fraud triangle theory is usually about the short-term interests of organizations or individuals [55].

For information: stakeholder theory advocates open and shared information; fraud triangle theory requires an information monopoly and blockade [56].

For interests: stakeholder theory implies the interests of the various stakeholders can be compromised or balanced against each other [57]; the fraud triangle theory implies fraudsters seek to maximize self-interest [58].

For alleviating conflict: stakeholder theory implies dialogue and negotiation [57]; fraud triangle theory implies self-rationalization [56].

For social contract: stakeholder theory was developed based on social contracts and support social contracts [59-61]; fraud triangle theory explored how fraudsters violate and betray social contracts [62].

The ontological differences between stakeholder theory and fraud triangle theory are briefly summarized as the following Table 2 shows.

According to fraud triangle theory, fraud comes into being under perceived pressure, opportunity and rationalization.

For perceived pressure: local gross domestic product (GDP) growth incentive is closely related to career evaluation for local officials, who accordingly prefer providing local protection to local polluting companies with the aim of promoting local economic growth. GDP growth incentive and career evaluation become a perceived pressure on local governmental officials to conduct information disclosure fraud. 
Table 2. The ontological differences between stakeholder theory and fraud triangle theory.

\begin{tabular}{ccc}
\hline Aspects & Stakeholder Theory & Fraud Triangle Theory \\
\hline legitimacy & normal & illegal \\
level & strategy & tactic \\
time span & long-term & short-term \\
information & open and share & monopoly and blockade \\
interest & compromised or balanced & maximization of self-interest \\
alleviating conflict & dialogue and negotiation & self-rationalization \\
social contract & based on and support & violate and betray \\
\hline
\end{tabular}

For perceived opportunity, incentive incompatibility, information asymmetry, and environmental information monopoly provide opportunities for local governmental officials to conduct information disclosure fraud. Local governments have superiority in occupying valuable information, and have more power in deciding what/how/when to disclose. Local environmental bureaux (LEB) usually obey the orders of local provincial or municipal governments in disclosing relevant information. Although LEB is fundamental in probing pollution information, LEB was administrated by local governments who provide jobs and salaries for the personnel of LEB. Local governments thus actually have a dominant role in determining what/how/when to disclose information. This is evidenced by referring to the similarities of two representative cases: the Songhua River pollution and the Changzhi aniline leakage. Both cases were briefly described in the literature [1]. There are 7 years between the two cases; however, in both cases, the local governments have deliberately delayed the disclosure of the truth until they felt the situation was uncontrollable. A major reason for covering the facts is to minimize public attention and potential penalty to local protectionism, while such practice has deep institutional roots [1].

For rationalization, there are some common reasons, such as maintaining local economic growth, keeping local social stability, having no expertise in coping with water pollution incidents, and so on.

It is not surprising to see the delay of information disclosure for major water pollution incidents as a result of the existence of fraud triangles among local governments.

The research question is: what are the roles of the typical actors in the information disclosure, and how can efficient information disclosure be achieved? This paper aims to unearth the latent resistance of information disclosure by analyzing the roles of different actors in information disclosure, and analyzing institutional implications and countermeasures. The following Sections 4 and 5 empirically verify actors' roles. The results support using fraud triangle theory for explanation and reveal clues on the latent resistance to information disclosure. Section 6 provides a discussion about the result, and analyzes countermeasures to mitigate with the problems.

\section{Materials and Methods}

This paper uses content analysis to identify the roles of actors in information disclosure so as to diagnose latent resistance. Content analysis has the merits of flexibility and repeatability, and is not obtrusive [63]; it is therefore useful for abstracting scattered secondary data from multiple textual/qualitative sources for the purpose of measuring interest [64]. The data of related information disclosures were mined from official news reports about representative incidents, and network analysis tools were applied to show the roles of actors, covering polluters, communities, environmental protection agencies, local governments, news media, the public, NGOs, insiders, experts or scholars, and water supply plants. Official news reports have the merit of being openly accessible and informative about facts. Data mined from official news reports on water pollution incidents provide an objective basis to assess the aforementioned actors' roles. Longitudinal cases based analytical methods are suitable for such research intention [1].

We selected total 10 representative cases from 2004 to 2013 (details shown in Table 3). Here, the term 'representative case' means a water pollution incident that has become a social focus event and 
has drawn national or even international attention, and was ranked as one of the most significant news items of that year. Such influential water pollution incidents can be called 'representative cases'. We select one case per year, except case 10, which despite having taken place on 31 December 2012, essentially influenced 2013. Therefore, it may be seen a case from 2013.

Table 3. Brief introduction of representative cases.

\begin{tabular}{|c|c|c|c|}
\hline No. & $\begin{array}{l}\text { Incident Name, Province and } \\
\text { Outbreak Date }\end{array}$ & Information Disclosure Delay & Consequence \\
\hline 1 & $\begin{array}{l}\text { Tuojiang River pollution in } \\
\text { Sichuan (16 February 2004) }\end{array}$ & $\begin{array}{l}\text { Information disclosure was delayed } \\
20 \text { days [65]. }\end{array}$ & $\begin{array}{l}\text { Millions of people living along the river } \\
\text { suffered suspension of water supplies; } \\
\text { direct economic loss was more than a } \\
\text { hundred million renminbi [65]. }\end{array}$ \\
\hline 2 & $\begin{array}{l}\text { Songhua River pollution occurred } \\
\text { in Jilin (20 November 2005) }\end{array}$ & The truth was concealed 9 days [66]. & $\begin{array}{l}\text { Water supply of the downstream Harbin } \\
\text { city had been shut for four days, and the } \\
\text { city once fell into panic [67]. The } \\
\text { subsequent contamination removing plan } \\
\text { cost } 26.6 \text { billion renminbi [68]. }\end{array}$ \\
\hline 3 & $\begin{array}{l}\text { Yueyang arsenic pollution in } \\
\text { Hunan (6 September 2006) }\end{array}$ & $\begin{array}{l}\text { Information disclosure was delayed } \\
2 \text { days [69]. }\end{array}$ & $\begin{array}{l}\text { The lives of } 100,000 \text { residents were under } \\
\text { threat [69]. }\end{array}$ \\
\hline 4 & $\begin{array}{l}\text { Taihu Lake cyanobacterial bloom } \\
\text { occurred in Jiangshu ( } 25 \text { April } \\
\text { 2007) }\end{array}$ & $\begin{array}{l}\text { Information disclosure was delayed } \\
3 \text { days [70]. }\end{array}$ & $\begin{array}{l}\text { Two million residents in Wuxi suffered tap } \\
\text { water deterioration and drinking water } \\
\text { shortages [23]. Some schools and colleges } \\
\text { suspended classes; the price of bottled } \\
\text { water sky-rocketed; panic occured mond } \\
\text { the public [70]. }\end{array}$ \\
\hline 5 & $\begin{array}{l}\text { Yangzonghai Lake arsenic } \\
\text { contamination occurred in } \\
\text { Yunnan (19 September 2008) }\end{array}$ & $\begin{array}{l}\text { Information disclosure was } \\
\text { Information disclosure was delayed } \\
\text { about one month [71]. }\end{array}$ & $\begin{array}{l}\text { In order to improve water quality, an } \\
\text { investment plan reached } 1.14 \text { billion } \\
\text { renminbi; experts predicted the cost would } \\
\text { reach } 4 \text { to } 7 \text { billion renminbi to thoroughly } \\
\text { remedy the water quality of Yangzonghai } \\
\text { Lake [72]. }\end{array}$ \\
\hline 6 & $\begin{array}{l}\text { Chifeng water pollution occurred } \\
\text { in Inner Mongolia (23 July 2009) }\end{array}$ & $\begin{array}{l}\text { Information disclosure was delayed } \\
3 \text { days [73]. }\end{array}$ & $\begin{array}{l}\text { More than } 4000 \text { residents fell ill and were } \\
\text { hospitalized [73]. }\end{array}$ \\
\hline 7 & $\begin{array}{l}\text { Zijin Mining Corporation } \\
\text { pollution in Fujian (3 July 2010) }\end{array}$ & The fact was concealed 9 days [74]. & $\begin{array}{l}\text { Direct economic losses amounted to } 31.877 \\
\text { million renminbi [75]. }\end{array}$ \\
\hline 8 & $\begin{array}{l}\text { Jiangxi Copper Corporation } \\
\text { wastewater pollution in Jiangxi (7 } \\
\text { December 2011) }\end{array}$ & $\begin{array}{l}\text { The fact about water pollution had } \\
\text { been concealed for many years [76]. }\end{array}$ & $\begin{array}{l}\text { Over } 420,000 \text { residents downstream } \\
\text { suffered health risks and } 71 \text { residents in the } \\
\text { Dai village died from cancers related to the } \\
\text { pollution [77]. }\end{array}$ \\
\hline 9 & $\begin{array}{l}\text { Longjiang River cadmium } \\
\text { contamination in Guangdong } \\
\text { (15 January 2012) }\end{array}$ & $\begin{array}{l}\text { Information disclosure was delayed } \\
10 \text { days [78]. }\end{array}$ & $\begin{array}{l}\text { Many fishermen and more than } 3 \text { million } \\
\text { residents were affected. } 1.33 \text { million baby } \\
\text { fish and } 40,000 \mathrm{~kg} \text { of adult fish died [79]. }\end{array}$ \\
\hline 10 & $\begin{array}{l}\text { Changzhi aniline leakage in } \\
\text { Shanxi (31 December 2012) }\end{array}$ & $\begin{array}{l}\text { Information disclosure was delayed } \\
5 \text { days [80]. }\end{array}$ & $\begin{array}{l}\text { Millions of residents in provinces Shanxi, } \\
\text { Henan and Heibei suffered water crisis [80]. }\end{array}$ \\
\hline
\end{tabular}

For each incident, relevant news reports were searched from Baidu, the largest web search engine in China, which supports search by subject and within a certain news website. The information source involved China's official news websites such as Xinhua News Agency, People's Net, Legal Daily, China News Net, China Economy Net and so on, and some local official news websites.

Through content analysis and research experience, relevant actors for information disclosure were classified and given symbols to briefly denote types, as shown in Table 4.

Based on a content analysis of the facts of the incidents, we recorded the clues of information disclosure and the actors who were responsible for information disclosure. The software UCINET (see https://sites.google.com/site/ucinetsoftware/home), with a function for analyzing centrality, is well-suited to fulfilling the task of presenting the relative roles of actors in information disclosure for the representative cases. Here, 'centrality' means whether the role of an actor in information disclosure is relatively superior or not. By comparison of the centralities of the actors, we can easily ascertain the roles of different actors and sense what may be wrong with the situation, and therefore, extrapolate possible remedial solutions. 
Table 4. Symbols denoting actor types.

\begin{tabular}{cl}
\hline Symbols & Actor Types \\
\hline A1 & Polluter \\
A2 & Polluter related firms \\
B1 & Local community \\
B2 & Downstream community \\
D1 & Local provincial government \\
D2 & Local municipal government or local frontline government \\
D3 & Downstream government \\
E1 & Local provincial environmental protection department \\
E2 & Local municipal environmental protection bureau or local frontline environmental protection agency \\
E3 & Downstream environmental protection agency \\
F & Public \\
G & NGOs \\
H & Insiders \\
I & Experts or scholars \\
J & Water supply plants \\
K & News media \\
\hline
\end{tabular}

\section{Results}

The distribution of the centralities of actors is shown in Figure 8.

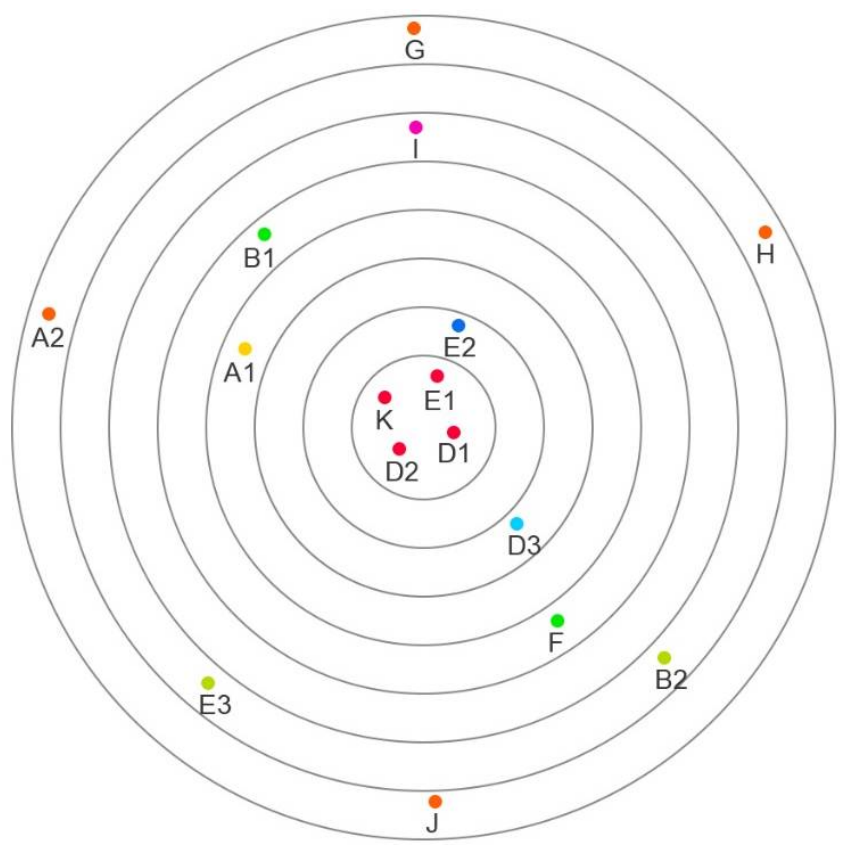

Figure 8. Centralities of actors.

Figure 8 shows that symbols K, E1, D1 and D2 locate at the center of the network in terms of centralities. That is, news media, local provincial environmental protection department, local provincial government, local municipal government, or local frontline government are central in disclosing information. Symbols G, A2, J and $\mathrm{H}$ locate in the most remote positions relative to other actors, meaning that NGOs, polluter related firms, water supply plants, and insiders seldom take the initiative in disclosing information.

The results confirm the dominance of the local government agencies (including local provincial environmental protection department, local provincial government, local municipal government, or local frontline government) in disclosing relevant information. Although the news media has superiority in disclosing information, the source information often comes from interviewing others. 
Due to an initial information monopoly, NGOs are at a disadvantage, and accordingly are unable to disclose fresh information. Water supply plants are affiliated with local municipal governments; therefore, they are required to wait and obey instructions from superiors. Insiders are told by their superiors to maintain silence. For example, in the Case 10, the Changzhi aniline leakage incident, the employees of the polluting factory were told not to talk about the incident [81]. In Figure 8, it is no wonder that symbols $\mathrm{G}, \mathrm{A} 2$, J and $\mathrm{H}$ locate at remote positions relative to the other actors, due to constraints in obtaining source information or risks of perceived betrayal.

\section{Discussion}

The results imply that the hierarchical control of local governments on the information disclosure limits transparency, and induces information disclosure fraud. The impetus to seek facts often comes from external pressure. Downstream panic is a factor. The news media serves as an interface to draw public attention and sway public opinion on information disclosure progress. Attention from the central government level also accelerates the disclosure of facts. Since effective and immediate responses in the immediate aftermath (the first hours and days) of water pollution incidents are critical in mitigating water contamination risks [82], it is disappointed to see that opportunities of resilience lost and situations deteriorated into water crises.

The fraud triangle is accordingly confirmed to be applicable in explaining information disclosure delays. The attitudes and behaviors of local governments are the reflection of latent defects of institutional arrangements. As a countermeasure, on 20 July 2015, MEP issued "Measures for Public Participation in Environmental Protection" (MPPEP), which endowed citizens, legal persons and other organizations with the right to report poorly performing local governments and LEBs to the higher authorities or supervisory agencies [83]. MPPEP is a great complement to China's Environmental Protection Law (EPL), which "fails to acknowledge citizens' basic right to an environment fit for life" [84] (p. 434).

MPPEP, which was formally implemented on 1 September 2015, represents great progress in acknowledging citizens' right to know, to participate, and to supervise environmental issues, providing guideline for citizens' environmental involvement, contributing to the democratization of environmental governance.

Acknowledging citizens' right to environmental surveillance is revolutionary, but further steps need to be carried out. China has recently made the decision to change the relationship of the administrative subordination of LEBs, which has been determined to be separated from local administrative subordination, and administrated by the environmental department. This change may reduce local interference and contribute to independent implementation of the EPL [85].

Based on this institutional change, possible further steps might include developing information disclosure and risk communication agencies affiliated to MEP and environmental NGOs, so as to triangulate the disclosed information by three parties: local government, MEP and NGOs. An agency in MEP can be specifically responsible for collecting data about hazards from industrial discharges, and make daily disclosures to the public about the risks. NGOs, such as the Institute of Public \& Environmental Affairs (IPE), can participate in data collection, disclosure and communication. The central government can deploy metagovernance initiatives [86] to involve more actors in environmental surveillance and communication. Different channels of information disclosure, transparency and communication can avoid information asymmetry and monopoly, and accordingly, reduce of the chance of information disclosure fraud.

It should also be noted that weak enforcement [87] and fewer environmental incentives on local governments may still threaten local environmental protection initiatives, which may have better performance in affluent areas, in which environmental activism by residents is strong, in contrast to poorer areas, in which residents deem environmental protection as a luxury [88]. Local governments may use latent means to protect local polluters in order to promote local economic growth, for example, using government subsidies to support polluters or emitters [89]. 
Therefore, to solve the problem at the root, the endogenous motivation for environmental protection must be activated. It is fundamental to design proper institutional arrangements to reconcile the relationship between economic growth and environmental protection. A way is to establish comprehensive green metrics on local official evaluation, whereby local officials obtain benefits based upon environmental performance [90]. A case in point is the town of Machong, which is affiliated to Dongguan city in Guangdong Province. The local government there changed a local polluted river area into a wetland park for tourism by shutting down surrounding polluting factories and investing in improving local ecology. Accordingly, this transformation achieves economic and ecological benefits, and simultaneously, is praised by local residents [91]. Other areas, such as Zhejiang province and Beijing, have involved citizens in the surveillance of rivers to monitor waste discharge; the surveillance results have even been linked to evaluations of local officials [92,93]. That is to say, economic growth, environmental improvement, and officials' political futures can be brought into sync. Leading firms and governments should take initiatives to build socially and environmentally responsible value chains [94], and to promote extensive corporate eco-innovation [5], which is the essential way to solve the problem of industrial pollution.

The above analysis implies that the essence of coping with the latent resistance in information disclosure is to rectify the mode of interest towards development, and to promote the widespread of environmental improvement motivation. It is also important to involve extensive actors in environmental surveillance in order to achieve transparency and efficient environmental governance.

\section{Conclusions}

Information disclosure after water pollution incidents is critical for subsequent efforts to minimize impact [82]. This paper studied information disclosures on hazards from industrial water pollution incidents in China. Empirical analysis on longitudinal cases verified the use of fraud triangle theory for phenomenon explanation. The results show that local government agencies occupy a dominant position in information disclosure, but that some important actors rarely participate in information disclosure, providing a chance for local government agencies to commit information disclosure fraud. Latent resistance and countermeasures were analyzed, highlighting the internal causalities, engaging in dialogue with recent policies, and providing enlightening commentary on contemporary practices. This paper illuminates the following promising topics for future research.

- Investigation of information disclosure related decisions embedded in an institutional framework. Understanding the mechanism of how institutional arrangements shaping decisions on information disclosure will contribute to discovering potential ways to rectify institutional deviation and avoid administrative fraud.

- Development of convenient information disclosure platforms for public environmental participation. There are more than one billion mobile devices in China, offering huge potential for citizen to use mobile apps to collect and monitor environmental data [95], promising to realize efficient environmental surveillance and transparent environmental information in an era of big data. This way can contribute to reducing the risk of information disclosure fraud.

- Designing socially and environmentally responsible value chains and incentive compatibility mechanisms to promote extensive corporate eco-innovation, so as to fundamentally reduce pollution.

Author Contributions: Y.T. drafted the manuscript and contributed to materials and analysis. X.M. conceptualized and designed the study. X.M., H.Z. and Y.G. revised the manuscript.

Acknowledgments: This work is supported by the National Natural Science Foundation of China (Grant No. 71471047), and the Humanities and Social Science Foundation of Ministry of Education (Grant No. 15YJC630116).

Conflicts of Interest: The authors declare no conflict of interest. 


\section{References}

1. Miao, X.; Tang, Y.; Wong, C.W.Y.; Zang, H. The latent causal chain of industrial water pollution in China. Environ. Pollut. 2015, 196, 473-477. [CrossRef] [PubMed]

2. Wang, Q.; Yang, Z.M. Industrial water pollution, water environment treatment, and health risks in China. Environ. Pollut. 2016, 218, 358-365. [CrossRef] [PubMed]

3. Yao, H.; You, Z.; Liu, B. Economic estimation of the losses caused by surface water pollution accidents in China from the perspective of water bodies' functions. Int. J. Environ. Res. Public Health 2016, $13,154$. [CrossRef] [PubMed]

4. Dahlander, L.; Gann, D.M. How open is innovation? Res. Policy 2010, 39, 699-709. [CrossRef]

5. He, F.; Miao, X.; Wong, C.Y.W.; Lee, S. Contemporary corporate eco-innovation research: A systematic review. J. Clean. Prod. 2018, 174, 502-526. [CrossRef]

6. Fifka, M.S. Corporate responsibility reporting and its determinants in comparative perspective-A review of the empirical literature and a meta-analysis. Bus. Strategy Environ. 2013, 22, 1-35. [CrossRef]

7. Meng, X.H.; Zeng, S.X.; Tam, C.M.; Xu, X.D. Whether top executives' turnover influences environmental responsibility: From the perspective of environmental information disclosure. J. Bus. Ethics 2013, 114, 341-353. [CrossRef]

8. Weber, O. Corporate sustainability and financial performance of Chinese banks. Sustain. Account. Manag. Policy J. 2017, 8, 358-385. [CrossRef]

9. Chen, H.; Zeng, S.; Lin, H.; Ma, H.Y. Munificence, dynamism, and complexity: How industry context drives corporate sustainability. Bus. Strategy Environ. 2017, 26, 125-141. [CrossRef]

10. Zhang, C. Political connections and corporate environmental responsibility: Adopting or escaping? Energy Econ. 2017, 68, 539-547. [CrossRef]

11. Li, D.; Cao, C.; Zhang, L.; Chen, X.H.; Ren, S.G.; Zhao, Y.N. Effects of corporate environmental responsibility on financial performance: The moderating role of government regulation and organizational slack. J. Clean. Prod. 2017, 166, 1323-1334. [CrossRef]

12. Zeng, S.X.; Xu, X.D.; Dong, Z.Y.; Tam, V.W.Y. Towards corporate environmental information disclosure: An empirical study in China. J. Clean. Prod. 2010, 18, 1142-1148. [CrossRef]

13. Holm, C.; Rikhardsson, P. Experienced and novice investors: Does environmental information influence investment allocation decisions? Eur. Account. Rev. 2008, 17, 537-557. [CrossRef]

14. Liu, X.; Wang, C.; Shishime, T.; Fujitsuka, T. Environmental activisms of firm's neighboring residents: An empirical study in China. J. Clean. Prod. 2010, 18, 1001-1008. [CrossRef]

15. Lyon, T.P.; Shimshack, J.P. Environmental disclosure: Evidence from newsweek's green companies rankings. Bus. Soc. 2015, 54, 632-675. [CrossRef]

16. Huang, R.; Chen, D. Does environmental information disclosure benefit waste discharge reduction? Evidence from China. J. Bus. Ethics 2015, 129, 535-552. [CrossRef]

17. Wang, X. Requests for environmental information disclosure in China: An understanding from legal mobilization and citizen activism. J. Contemp. China 2016, 25, 233-247. [CrossRef]

18. Hassan, A.; Ibrahim, E. Corporate environmental information disclosure: Factors influencing companies' success in attaining environmental awards. Corp. Soc. Responsib. Environ. Manag. 2012, 19, 32-46. [CrossRef]

19. Li, D.; Zhao, Y.; Sun, Y.; Yin, D.J.Y. Corporate environmental performance, environmental information disclosure, and financial performance: Evidence from China. Hum. Ecol. Risk Assess. 2017, 23, 323-339. [CrossRef]

20. Istrate, C.; Robu, I.B.; Pavaloaia, L.; Herghiligiu, I.V. Analysis of companies sustainability under the influence of environmental information disclosure. Environ. Eng. Manag. J. 2017, 16, 957-967.

21. Kasim, M.T. Evaluating the effectiveness of an environmental disclosure policy: An application to New South Wales. Resource Energy Econ. 2017, 49, 113-131. [CrossRef]

22. Yu, Y.; Huang, J.; Luo, N. Can more environmental information disclosure lead to higher eco-efficiency? Evidence from China. Sustainability 2018, 10, 528.

23. Zhang, L.; Mol, A.P.J.; He, G.; Lu, Y.L. An implementation assessment of China's environmental information disclosure decree. J. Environ. Sci.-China 2010, 22, 1649-1656. [CrossRef]

24. Zhao, Y. Public participation in China's EIA regime: Rhetoric or reality? J. Environ. Law 2010, 22, 89-123. [CrossRef] 
25. Song, X.; Mulder, K.; Frostell, B.; Ravesteijn, W.; Wennersten, R. Transition in public participation in Chinese water management. Proc. Inst. Civil Eng.-Eng. Sustain. 2011, 164, 71-83. [CrossRef]

26. Johnson, T. Environmental information disclosure in China: Policy developments and NGO responses. Policy Polit. 2011, 39, 399-416. [CrossRef]

27. He, G.; Mol, A.P.J.; Zhang, L.; Lu, Y.L. Public participation and trust in nuclear power development in China. Renew. Sustain. Energy Rev. 2013, 23, 1-11. [CrossRef]

28. Huang, T.; Yue, Q. A borrowed cloak: The institutional bottlenecks to legislating environmental information disclosure by Chinese listed corporations. J. Environ. Law 2017, 29, 445-473. [CrossRef]

29. Cho, C.H.; Freedman, M.; Patten, D.M. Corporate disclosure of environmental capital expenditures a test of alternative theories. Account. Audit. Account. J. 2012, 25, 486-507. [CrossRef]

30. Zeng, S.X.; Xu, X.D.; Yin, H.T.; Tam, C.M. Factors that drive Chinese listed companies in voluntary disclosure of environmental information. J. Bus. Ethics 2012, 109, 309-321. [CrossRef]

31. Kuo, L.; Yeh, C.C.; Yu, H.C. Disclosure of corporate social responsibility and environmental management: Evidence from China. Corp. Soc. Responsib. Environ. Manag. 2012, 19, 273-287. [CrossRef]

32. Meng, X.H.; Zeng, S.X.; Tam, C.M. From voluntarism to regulation: A study on ownership, economic performance and corporate environmental information disclosure in China. J. Bus. Ethics 2013, 116, $217-232$. [CrossRef]

33. Doshi, A.R.; Dowell, G.W.S.; Toffel, M.W. How firms respond to mandatory information disclosure. Strateg. Manag. J. 2013, 34, 1209-1231. [CrossRef]

34. Lewis, B.W.; Walls, J.L.; Dowell, G.W.S. Difference in degrees: CEO characteristics and firm environmental disclosure. Strateg. Manag. J. 2014, 35, 712-722. [CrossRef]

35. Meng, X.H.; Zeng, S.X.; Leung, A.W.T.; Tam, C.M. Relationship between top executives' characteristics and corporate environmental responsibility: Evidence from China. Hum. Ecol. Risk Assess. 2015, 21, 466-491. [CrossRef]

36. Li, D.; Xin, L.; Sun, Y.; Huang, M.; Ren, S.G. Assessing Environmental Information Disclosures and the Effects of Chinese Nonferrous Metal Companies. Polish J. Environ. Stud. 2016, 25, 663-671. [CrossRef]

37. Tian, X.L.; Guo, Q.G.; Han, C.; Ahmad, N. Different extent of environmental information disclosure across Chinese cities: Contributing factors and correlation with local pollution. Glob. Environ. Chang.-Hum. Policy Dimens. 2016, 39, 244-257. [CrossRef]

38. Yao, S.; Liang, H. Firm location, political geography and environmental information disclosure. Appl. Econ. 2017, 49, 251-262. [CrossRef]

39. Cheng, Z.; Wang, F.; Keung, C.; Bai, Y.X. Will corporate political connection influence the environmental information disclosure level? Based on the panel data of A-Shares from listed companies in Shanghai stock market. J. Bus. Ethics 2017, 143, 209-221. [CrossRef]

40. Yao, S.; Yang, J. Geographical distance and environmental information disclosure: The perspective of public pressure transmission efficiency. Asia-Pac. J. Financ. Stud. 2017, 46, 445-462. [CrossRef]

41. Liu, X.; Anbumozhi, V. Determinant factors of corporate environmental information disclosure: An empirical study of Chinese listed companies. J. Clean. Prod. 2009, 17, 593-600. [CrossRef]

42. Kuo, L.; Yu, H.C.; Chang, B.G. The signals of green governance on mitigation of climate change-Evidence from Chinese firms. Int. J. Clim. Chang. Strateg. Manag. 2015, 7, 154-171. [CrossRef]

43. Noronha, C.; Leung, T.C.H.; Lei, O.I. Corporate social responsibility disclosure in Chinese railway companies corporate response after a major train accident. Sustain. Account. Manag. Policy J. 2015, 6, 446-474. [CrossRef]

44. Riley, T.; Huiya, C. Unmasking Chinese business enterprises: Using information disclosure laws to enhance public participation in corporate environmental decision making. Harv. Environ. Law Rev. 2009, 33, 177-224.

45. Li, W. Self-motivated versus forced disclosure of environmental information in China: A comparative case study of the pilot disclosure programmes. China Quart. 2011, 206, 331-351. [CrossRef]

46. Rodrigue, M. Contrasting realities: Corporate environmental disclosure and stakeholder-released information. Account. Audit. Account. 2014, 27, 119-149. [CrossRef]

47. Huang, C.L.; Kung, F.H. Drivers of environmental disclosure and stakeholder expectation: Evidence from Taiwan. J. Bus. Ethics 2010, 96, 435-451. [CrossRef]

48. Albrecht, W.S.; Albrecht, C.C.; Albrecht, C.O. Fraud and corporate executives: Agency, stewardship and broken trust. J. Forensic Account. 2004, 5, 109-130. 
49. Berman, S.L.; Wicks, A.C.; Kotha, S.; Jones, T.M. Does stakeholder orientation matter? The relationship between stakeholder management models and firm financial performance. Acad. Manag. J. 1999, 42, 488-506.

50. Jensen, M.C. Value maximization, stakeholder theory, and the corporate objective function. Bus. Ethics Quart. 2002, 12, 235-256. [CrossRef]

51. Rodgers, W.; Soderbom, A.; Guiral, A. Corporate social responsibility enhanced control systems reducing the likelihood of fraud. J. Bus. Ethics 2015, 131, 871-882. [CrossRef]

52. Freeman, E. Strategic Management: A Stakeholder Approach; Cambridge University Press: Cambridge, UK, 2010.

53. Murphy, P.R.; Dacin, M.T. Psychological pathways to fraud: Understanding and preventing fraud in organizations. J. Bus. Ethics 2011, 101, 601-618. [CrossRef]

54. Ruf, B.M.; Muralidhar, K.; Brown, R.M.; Janney, J.J.; Paul, K. An empirical investigation of the relationship between change in corporate social performance and financial performance: A stakeholder theory perspective. J. Bus. Ethics 2001, 32, 143-156. [CrossRef]

55. Chen, J.D.; Cumming, D.; Hou, W.X.; Lee, E. Does the external monitoring effect of financial analysts deter corporate fraud in China? J. Bus. Ethics 2016, 134, 727-742. [CrossRef]

56. Schuchter, A.; Levi, M. The fraud triangle revisited. Sec. J. 2016, 29, 107-121. [CrossRef]

57. Blattberg, C. "Welfare: Towards the Patriotic Corporation". From Pluralist to Patriotic Politics: Putting Practice First; Oxford University Press: New York, NY, USA, 2004; pp. 172-184.

58. Liu, X.K.; Wright, A.M.; Wu, Y.J. Managers' unethical fraudulent financial reporting: The effect of control strength and control framing. J. Bus. Ethic 2015, 129, 295-310. [CrossRef]

59. Mitchell, R.K.; Agle, B.R.; Wood, D.J. Toward a theory of stakeholder identification and salience: Defining the principle of who and what really counts. Acad. Manag. Rev. 1997, 22, 853-886. [CrossRef]

60. Donaldson, T.; Preston, L.E. The stakeholder theory of the corporation: Concepts, evidence, and implications. Acad. Manag. Rev. 1995, 20, 65-91. [CrossRef]

61. Mansell, S. Capitalism, Corporations and the Social Contract: A Critique of Stakeholder Theory; Cambridge University Press: Cambridge, UK, 2013.

62. Houdek, P. Professional identity and dishonest behavior. Society 2017, 54, 253-260. [CrossRef]

63. Tangpong, C. Content analytic approach to measuring constructs in operations and supply chain management. J. Oper. Manag. 2011, 29, 627-638. [CrossRef]

64. Wong, C.W.Y.; Miao, X.; Cui, S.; Tang, Y. Impact of corporate environmental responsibility on operating income: Moderating role of regional disparities in China. J. Bus. Ethics 2106, 1-20. [CrossRef]

65. Xinhua News Agency. 2004. Available online: http://news.xinhuanet.com/newscenter/2004-04/05/ content_1402136.htm (accessed on 10 April 2015).

66. Tang, J.G.; Wang, G.; Li, Y. They made up a reason. China Newsweek 2005, 11, 20-23.

67. Xinhua News Agency. 2005. Available online: http://news.xinhuanet.com/politics/2005-11/28/content_ 3848242.htm (accessed on 12 April 2015).

68. China News Net. 2006. Available online: http://www.chinanews.com/news/2006/2006-01-07/8/675054. shtml (accessed on 21 April 2015).

69. China Economy Net. 2006. Available online: http://www.ce.cn/xwzx/gnsz/gdxw/200609/18/t20060918_ 8601465.shtml (accessed on 10 April 2015).

70. China Youth Daily. 2007. Available online: http://zqb.cyol.com/content/2007-06/01/content_1779766.htm (accessed on 13 April 2015).

71. Xinhua News Agency. 2008. Available online: http://news.xinhuanet.com/newscenter/2008-10/27/ content_10257061_1.htm (accessed on 30 March 2015).

72. Green Living. 2013. Available online: http://www.hjysh.cn/_d276116044.htm (accessed on 15 April 2015).

73. People's Net. 2009. Available online: http:/ / politics.people.com.cn/GB/14562/10061888.html (accessed on 25 March 2015).

74. Southern Weekly. 2010. Available online: http://www.infzm.com/content/47527 (accessed on 29 March 2015).

75. Xinhua News Agency. 2010. Available online: http://news.xinhuanet.com/2010-10/08/c_12636854.htm (accessed on 16 April 2015).

76. Securities Times. 2011. Available online: http://epaper.stcn.com/paper/zqsb/html/2011-12/29/content 331083.htm (accessed on 5 April 2015). 
77. Evening News. 2013. Available online: http://newspaper.jfdaily.com/xwwb/html/2013-02/25/content_ 978062.htm (accessed on 15 April 2015).

78. Xinjiang Metropolis Daily. 2012. Available online: http://epaper.ts.cn/ftp/site1/xjdsb/html/2012-01/31/ content_158190.htm (accessed on 16 April 2015).

79. JCRB. 2012. Available online: http://www.jcrb.com/zhuanti/shzt/gxgwr/ (accessed on 18 April 2015).

80. Legal Daily. 2013. Available online: http://www.legaldaily.com.cn/The_analysis_of_public_opinion/ content/2013-02/06/content_4183953.htm (accessed on 22 April 2015).

81. Fawan News. Available online: http:/ /www.fawan.com/Article/gn/jd/2013/02/14/125838186587.html (accessed on 2 April 2017).

82. Tang, Y.; Wu, S.; Miao, X.; Pollard, S.J.T.; Hrudey, S.E. Resilience to evolving drinking water contamination risks: A human error prevention perspective. J. Clean. Prod. 2013, 57, 228-237. [CrossRef]

83. Ministry of Environmental Protection of China. Available online: http:/ / www.gov.cn/zhengce/2015-07/ 22/content_2900767.htm (accessed on 6 August 2017).

84. Zhang, B.; Cao, C. Four gaps in China's new environmental law. Nature 2015, 517, 433-434. [CrossRef] [PubMed]

85. Xinhua News Agency. Available online: http://news.xinhuanet.com/fortune/2015-10/29/c_1116983078. htm (accessed on 18 September 2017).

86. Tang, Y.; Ma, Y.; Wong, C.W.Y.; Miao, X. Evolution of government policies on guiding corporate social responsibility in China. Sustainability 2018, 10, 741. [CrossRef]

87. Yang, H.; Huang, X.J.; Thompson, J.R.; Flower, R.J. Enforcement key to China's environment. Science 2015, 347, 834-835. [CrossRef] [PubMed]

88. Miao, X.; Tang, Y.; Wong, C.W.Y. Polluters migrate to China's poor areas. Nature 2015, 518, 483. [CrossRef] [PubMed]

89. Miao, X. China emissions: Stop subsidizing emitters. Nature 2015, 527, 38. [CrossRef] [PubMed]

90. Zhang, H.M.; Xiong, L.F.; Qiu, Y.M.; Zhou, D.Q. How have political incentives for local officials reduced environmental pollution in resource-depleted cities? Sustainability 2017, 9, 1941. [CrossRef]

91. Dongguan Sunshine Net. Available online: http://news.sun0769.com/town/ms/201505/t20150516_ 5367400.shtml (accessed on 8 September 2017).

92. Zhang, T.; Zheng, F.; Yu, T. Citizens arrest river pollution in China. Nature 2016, 535, 231. [CrossRef] [PubMed]

93. China News Net. Available online: http://www.chinanews.com/gn/2017/11-25/8385173.shtml (accessed on 25 November 2017).

94. Lee, H.L.; Tang, C.S. Socially and environmentally responsible value chain innovations: New operations management research opportunities. Manag. Sci. 2018, 64, 983-996. [CrossRef]

95. Zhang, J.; Huang, X. China needs more monitoring apps. Nature 2015, 520, 436. [CrossRef] [PubMed] 